\title{
МОНГОЛ ОРНЫ ЭРДЭСТ НУУРУУДЫН ЛИТИЙ, УРАНЫ СУДАЛГАА
}

\author{
С.Ариунбилэг \\ ШУА-ийн Геологи, эрдэс баялеийн хүрээлэн, эшаа. \\ s_ariunbileg@yahoo.com
}

\begin{abstract}
For the last 30 years Central Asian and other countries closed salted lakes containing $L i, U$ and other rare elements $(B, B r . J)$ are explored and used as an energy resources. Thus, it is important to study and practice our country' salt lakes which contains $\mathrm{Li}, U$ and other elements.
\end{abstract}

\section{Оршил}

Орчин үед геологийн шинжлэх ухааны суурь судалгааг үйлдвэрлэлийн үйл ажиллагаатай холбож, шинэ техник, технологийн үйлдвэрлэлд-хасах эрэлт хэрэгцээтэй эрдэс-түүхий эдийн баялгыг илрүүлэх чухал шаардлага тавигдаж байна. Сүүлийн 30 гаруй жилийн өмнөөс Төв Азийн болон бусад олон орны эрдэст нууруудын шорвог уусмалаас литий, уран, бусад ховор элементүүд /бор, бром, иод / -ийг гарган авч [Garrett, 2004; Moores, 2007; Ляхов, Владимиров, Исупов ба бусад, 2008; Gruber, Medina, 2010], эрдэсжилт ихтэй нууруудын судалгаа эрчимжиж, ашигт малтмалын баялгийн нэг шинэ төрөл болон хөгжиж байна. Эх газрын эрдэсжилт ихтэй давстай нууруудад Li , U болон түүнийг дагаж хуримтлагддаг $\mathrm{B}, \mathrm{Br}, \mathrm{Rb}, \mathrm{Sr}$ ба K-ийн эрдэсжилт нь хуурай халуун уур амьсгалтай, ууршилт ихтэй нөхцөлд эх газрын галт уулын болон шүлтлэг чулуулгийн исэлдэлтээс үүсч нуурын ай савыг даган давстай нуурт хуримтлагддаг байна. 1960-аад онд Чили (салар Атакама Li- 900-7000 мг/л), Боливи (салар Уюни, Li-80-1150 мг/л)-д, 1980-аад оноос эхэлж Хятадын Төвдийн (Цзабуе, Цинхай-Li- 360-410г/л) нутагт литийн өндөр агууламжтай эрдэст нуурын усыг түүхий эдийн орд болгон ашиглаж байна. Зарим тохиолдолд эрдэсжилттэй нуурууд нь ураны хэтийн төлөв бүхий түгээмэл биш эx үүсвэр болдог байна [Mingkuan Qin, 2009]. Нөгөө талаас нуур, булгийн усанд литий, ураны хэмжээг тогтоосноор эдгээр элементээр баяжсан усыг хүн, малын ундны хэрэгцээнд хэрэглэхгүй байхыг тодорхойлдог. Иймээс хүрээлэн буй орчны геоэкологийн үнэлгээнд энэ судалгааны үр дүнг шинээр оруулах асуудал гарч ирж байна.

\section{Судалсан байдал}

Манай орны нутагт Дэлхийн усны ай савын Төв Азийн гадагш урсгалгүй эрдэсжилт ихтэй давстай нуурууд өргөн тархалттай оршдог. Монгол орны эрдэст нууруудын гидрогеологи, гидрохимийн судалгаанууд 1961 оноос хойш нилээд хийгдсэн боловч нуурын усны химийн найрлага, хэмжээ, нуурын давс, түүнийг ашиглах талаар голлон анхаарч [Лувсандорж, 1973; Рассказов, 1991; Цэрэнсодном, 2000; Писарский, 2003], нуурын усны микроэлементийн (литий, бор, бром, уран болон бусад) судалгаа бараг хийгдээгүй байна. Монгол орны эрдэст нуурын өмнөх 
судалгааны ажлууд болон эрдсээр баялаг нууруудын онцлог, тархалтын зүй тогтлыг дүгнэж үзээд манай орны эрдэст нуурын хурдсанд (гидроминераль гаралтай Li, Sr, $\mathrm{Br}, \mathrm{B}, \mathrm{U}$ ) шинэ төрлийн ашигт малтмал үүсэх тохиромжтой нөхцөлүүд бүрдсэн гэж үзсэн. Үүнд:

- Манай орны нутагт Төв Азийн гадагш урсацгүй 180 гаруй эрдэстэй нуурууд оршдог (Лувсандорж.Ж 1973).

- Эрдэст нууруудын усны эрдэсжилтийн хэмжээ - дундажаар 300 г/л хүртэл, найрлагаараа хлорт натри, карбонат, сульфат натрийн төрөлд багтдаг (Рассказов А.А., Лувсандорж Ж бусад., 1991).

- Нууруудын хотгор нь тектоник хөдөлгөөний үр дүнд үүссэн, ихэвчлэн Mz$\mathrm{Kz}$ эриний эртний нууруудын үлдэгдэл, Дөрөвдөгчийн галавын эхээр болсон тектоник хөдөлгөөн нуурын орчин үеийн дүр төрхийг бий болгосон (Рассказов А.А., Лувсандорж Ж бусад., 1991)

- Эх газрын хуурай уур амьсгал, хур, тунадасны хэмжээ бага, ууршилт нь чийгшилтээс их зэрэг таатай нөхцөлтөй (Цэрэнсодном Ж 1971)

- Рашаан усны эрдэсжилтийн хэмжээ, хийн агуулга өндөр (Писарский Б.И., Ганчимэг, 2007)

Иймд манай улсын нутаг дэвсгэрийн гадагш урсгалгүй, эрдэсжилтийн хэмжээ ихтэй нууруудын ус, хурдсанд литий болон түүнийг дагалдах ( $\mathrm{B}, \mathrm{Br}, \mathrm{Sr}, \mathrm{U})$ бусад ховор элементүүдийг тодорхойлох геохими, гидрохимийн судалгаа явуулах нь эдгээр элементүүдийн тархалтын зүй тогтлыг судлаад зогсохгүй литий, ураны эрдэст усны (гидроминеральный) шинэ төрлийн түүхий эдийг илрүүлэх, шинжлэх ухааны онолын болон эрэл хайгуул, геоэкологийн асуудлуудыг цогцоор шийдвэрлэх, нөөцтөй талбайг илрүүлэх зэрэг олон талын ач холбогдолтой болно.

\section{Судалгааны аргачлал}

2007 оноос Монгол Улсын ШУА-ийн Геологи, эрдэс баялгийн хүрээлэн ба Оросын ШУА-Сибирийн Салбарын Новосибирск хотын Геологи, минералогийн хүрээлэнгийн хамтарсан гидрогеологи-геохимийн судалгаа эхэлсэн бөгөөд уг судалгааны ажилд А.Г.Владимиров, В.П.Исупов нарын эрдэмтэд оролцов. Уг хамтарсан судалгаа нь манай орны эрдэст нууруудын усны эрдэсжилтийн хэмжээг тогтоох, эрдэс бүрдүүлэх механизм, үүсэх нөхцөлийг тогтооход чиглэгдсэн бөгөөд судалгааны үр дүнд литий, уран, стронций, бром, (Li, B, Br, Sr, U) зэрэг микроэлементийн өндөр агуулгатай гидроминералийн түүхий эдийг илрүүлэх, өндөр агуулгатай гадагш урсгалгүй нууруудын загварыг боловсруулах, геоэкологийн үнэлгээ өгөх гол зорилготой байлаа. Энэ хугацаанд хамтарсан хээрийн судалгааны экспедицийг өөрийн орны нутагт 5 удаа зохион байгуулж 50 гаруй гидрохимийн янз бүрийн найрлагатай нуурын ус, ёроолын хурдасны лаг шаврын дээжлэлтийг хийж ховор элементийн шинжилгээг явуулав. Судалгаанд хамрагдсан нуурын байршилтыг зураг дээр харуулав. 


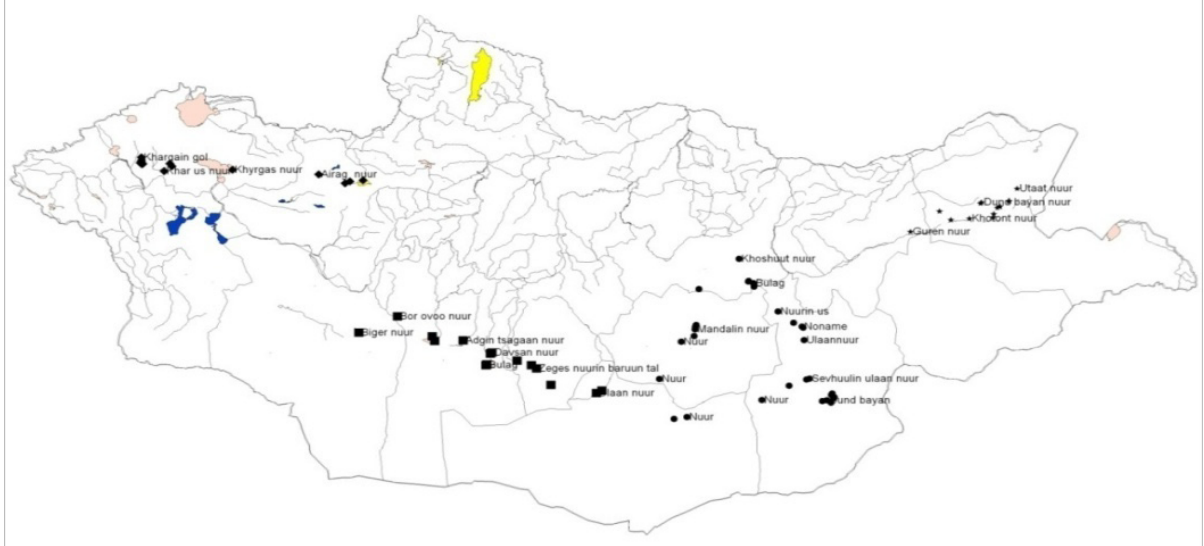

2007, 2009-2010 онуудад төслийн судалгаанд хамрагдсан нуурын байршилт

Нуурын эрдэсжилт, шорвог усны найрлага, уран болон микроэлементийн (As, В, Мо и др) шинжилгээг ОХУ-ын ШУА-ийн Сибирийн Салбарын Новосибирск хот дахь Геологи, минералогийн хүрээлэн, ОХУ-ын ШУА-ийн СС-ын Хатуу биеийн хими, механохимийн хүрээлэнгийн лабораторид индукт-холбоостой плазмын спектрометр Agilent 7500-аap, мөн атом-шингээлтийн ИСП (iCAP 6300 Duo, Thermo Scientific) багажаар тус тус тодорхойлсон. Нуурын давс, ёроолын лаг шаврын эрдсийн найрлагыг рентген фразын дифрактометр ДРОН-3М багаж дээр зэсийн анод, CuK $\alpha$ цацрагийн $2 \theta=10-70$ хэмжилтийг Search-Match программаар гүйцэтгэсэн. Нуурын усны $\mathrm{Na}, \mathrm{K}, \mathrm{Ca}, \mathrm{Mg}, \mathrm{Sr}$, Li болон хлор, карбонат, гидрокарбонат, сульфат-ионы агуулгыг Сатурн-2 М и Varian AA 280 FS спектрометрийн багаж дээр тус тус тодорхойлов.

\section{Судалгааны үр дүн}

Сүүлийн жилүүдийн Дэлхийн дулааралтын улмаас агаарын температур 20 орчим жилийн дотор 2-3 градусаар дулаарч манай орны цөлийн бүсийг хойшлуулж байгаа нь цэнгэг устай нуур цөөрөх, шорвог давстай том жижиг олон нууруудын ус ширгэх болон нуурын усны найрлага, эрдэсжилтийн хэмжээнд өөрчлөлт оруулж байна. Бидний судалгаанд хамрагдсан нууруудын усны эрдэсжилт нь нуурын газар зүйн байршилт, орон нутгийн өндөрлөг, нуур орчмын чулуулгийн геологийн тогтоц, нарны хэт ягаан цацрагийн хэмжээ болон нуурын усны рН орчин, хуурайшилт зэрэг уур амьсгалын өөрчлөлттөөс хамаарч өөрчлөгдөж байгааг тогтоолоо. Судалгаанд хамрагдсан Монгол орны нуурын усны химийн найрлага гидрокарбонатын ангид

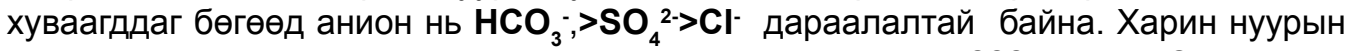
усны катионы харьцаагаар эрдэсжилтийг тодорхойлдог ??? хасах. Эрдэсжилт багатай, цэнгэг устай нуурын усны найрлаганд голдуу кальцийн ион зонхилох ба тэдгээрийн харьцаа ямагт $\mathbf{C a}^{2+}>\mathbf{N a}^{+}+\mathbf{K}^{+}>\mathbf{M g}^{2+}$ байх боловч нуурын байршилын өндөрлөг, хуурайшилт, ууршилт зэргээс хамаарч усны эрдэсжилт ихэсч байдаг 
учраас тэдгээр нууруудын усны анион, катионы харьцаа болон микроэлементийн агуулга, хэмжээ харилцан адилгүй болдог байна.

Дорнод Монголын Чойбалсан хотоос хойшхи тэгш тал, хээрийн бүс нутагт байрших хожуу цэрд-неогений эртний усан сангийн үлдэгдлээс гаралтай, гадагш урсгалгүй, голдуу улирлын усаар тэжээгдсэн тогтоол устай, эх газрын хуурай уур амьсгалын нөхцөлтөй, тектоник хуримтлалын гаралтай эртний хөндийнүүдийн жижиг хотгоруудад тогтсон 1-2 км² талбайтай, 0.2-1.0 м гүн устай хоорондоо холбоотой бага эрдэсжилттэй 19 нууруудыг судлав. Эдгээр нуурууд нь 732-762 м дундач өндөрлөгтөй тэгш тал газарт, зүүн-урдаас баруун хойш чиглэлд хөнтрүү налуувтар хавтгайд байрладаг ба нуурын эрдэсжилтийн химийн найрлага нь хойт хэсэгтээ Na-Mg-ийн сульфатын (шүү, давстай) дэд төрлийн байхад өмнөт хэсэгтээ карбонатын (хужир) төрөлд тус тус хамаарагдана. Чойбалсангийн неогены сав газарт байрших хуурайшилт, ууршилт нь хур тунадаснаас ихтэй ??? хамааралтай тал хээрийн бүсэнд байршилттай нууруудын катионы харьцаа $\mathrm{Na}^{+}+\mathrm{K}^{+}>\mathbf{M g}^{2+}>\mathbf{C a}^{2+}$ байдалтай байв. Өөрөөр хэлбэл натрий, калий давамгайлсан давс, хужир, шүүний химийн найрлагатай байна. Иймд эдгээр нууруудын усанд гидрокарбонатын уусалт ихэсч тэдгээрт $\mathrm{Li}, \mathrm{U}, \mathrm{Sr}, \mathrm{Br}$ агуулга өндөр байна. Гидрокарбонатын өндөр эрдэсжилттэй Цайдам, Гурваны, Шар бүрд, Хотонтын, Эрээний бүрд зэрэг нууранд ураны агуулга 0,3-2,4 мг/л хүрч бром, борын агуулга харилцан хамааралтайгаар ихсэж байгаа бөгөөд харин хлор, сульфатын ион давамгайлсан давс, шүүтэй Дунд Баян, Баруун Баян, Баруун давст, Зүүн давст зэрэг нууруудын усны найрлаганд литийн агуулга ихэсч 0,5-2,3 мг/л хүрч, мөн стронций, бромын агуулга өндөр болж байна. Дорнод Монголын хужиртай нууруудад ураны агуулга өндөр байгааг сүүлийн жилүүдэд бусад судлаачид (Benjamin at el.,2010; Linhoff at.el.,2007) тогтоосон байдаг. Дээрхи шинжилгээний үр дүнгээс үзэхэд Дорнод Монголын тэгш талын эрдсээр баялаг нууруудад Li, Sr, B, Br, U (r/л-ээр) микроэлементийн эерэг агуулга тогтоогдов. Эдгээр нуурууд нь хожуу мезозой-кайнозойн галт уулын идэвхжилттэй холбоотой үүссэн Дорнод Монголын эпитермаль гаралтай $\mathrm{Au}, \mathrm{Pb}$, хайлуур жоншны металлогенийн бүс ба мөн ураны орд, Не-ийн аномаль агуулгатай давхцаж байршдаг.

Нууруудын Хөндийн неогены сав газрын далайн төвшинөөс дээш 10451332 метр өндөрлөг хөндийд оршдог (Зураг 2 ) нууруудын судалгааг 2009 онд явуулав. Нууруудын Хөндийн нууруудын зүүн өмнөд хэсэг байршдаг Улаан нуур, Адгийн Цагаан, Орог, нуур, Таацын Цагаан зэрэг нуурууд сүүлийн 20 жилд ширгэж Дэлхийн дулааралт, уур амьсгалын өөрчлөлт, хүний буруутай үйл ажиллагаа зэргийг илэрхийлж байна. Одоогоор устай байгаа Бөөн Цагаан нуурын усны түвшин мөн багасч эргээр нь шавар шалбаагтай болжээ. Бэгэр Нуурын ус нилээд зузаан хужирын үеэр хучигдаж нуурын усны эрдэсжилтийн хэмжээ ихэссэн байна. Баянхонгор аймгийн Богд сумын ард орших Холбоолжин, Давст нууруудын ус их хэмжээгээр татарсан байна. Эдгээр нуурын ус өндөр эрдэсжилттэй болжээ. Давсан нуурын усны гадарга жижиг гэрийн буйрын хэмжээний олон тогоо хэлбэртэй тогтоцтой болж, дээгүүрээ ягаан өнгөтөй замаг, давс тогтсон байна. Мөн Буу цагаан сумын Бор овоогийн (Борвой нуур) давстай нуурын судалгааг явуулав. Бидний хийсэн нууруудын усны микрохимийн шинжилгээний үр дүнгээс үзвэл одоогийн Нууруудын Хөндийн зүүн өмнөд хэсэгт орших Мандал бригад, Төхөм булаг болон Орог нуурын ойролцоох булаг, шанд болон Бөөн Цагаан нуурын усны найрлаганд катионы харьцаа $\mathbf{C a}^{2+}>\mathbf{N a}^{+}+\mathbf{K}^{+}>\mathbf{M g}^{2+}$ байгаа ба дээрхи булаг шандны 
усан дахь Li, U, Sr, B, Br зэрэг микроэлементийн агуулга хэвийн хэмжээнд байна. Харин Бүрд, Зэгэс, Холбоолжин ( ${ }^{238} U-0.1$ мг/л), Давсан $\left({ }^{238} \mathrm{U}-0.132\right.$ мг/л ), Бор овоо (238U--0.118 мг/л , Li-1.0 мг/л) зэрэг шорвог давстай нууруудад уран, литий бусад дагалдах микроэлементийн хэмжээ нилээд өндөр байгааг тогтоож , тэдгээр нуурын усны катионы харьцаа $\mathbf{N a}^{+}+\mathbf{K}^{+}>\mathbf{M g}^{2+}>\mathbf{C a}^{2+}$ болон өөрчлөгдөж давс, хужирын эрдэсжилтийн хэмжээ ихэсч байгааг илрүүлэв. Үүнээс гадна Нууруудын Хөндийн Бэгэр нуурын ус сүүлийн жилүүдэд эрчимтэй ширгэж нуурын усны найрлага дахь катионы харьцаа $\mathbf{M g}^{2+}>\mathrm{Ca}^{2+}>\mathrm{Na}^{+}+\mathrm{K}^{+}$өөрчлөгдөн, магний давамгайлах болж, S-As, Sr-ийн агуулга өндөр хэмжээтэй байгааг илрүүлэв. Дээрхи нууруудын усны найрлага өөрчлөгдөж литий, уран мэтийн элементээр баяжигдаж байгаа нь нутаг дэвсгэр хуурай дулаан уур амьсгалтай болж, нуурын ус их хэмжээгээр ууршиж, нуурын усны эрдэсжилтэнд өөрчлөлт орж байгаагийн тод жишээ юм. Нууруудын Хөндийн плейстоцены мөслөгийн ул мөр болсон эртний эрэг, дэнжүүдийн өндөр үлдэцүүдийг харахад нууруудын усны түвшин одоогийнхоос бараг 200 гаруй метрээр их байсан байна (Goro Komatsu et al.,2001).

Баруун Монголын Их Нууруудын хотгорын плейстоцен-неогены хотгорын сав газрын хэмжээнд тархалттай манай орны томоохон нуурууд нь 1050 м-ээс дээш өндөрлөгт оршдог бөгөөд нууруудын усны эрдэсжилт 1-200 г/л хооронд хэлбэлзэж байна. Их Нууруудын хотгорын ихэнхи нууруудын усны найрлаганд гидрокарбонатын ион (290-2500мг/л) давамгайлж, карбонатын ион (0,4-600 мг/л) нилээд хэмжээгээр агуулагдаж байгаа ба катионы харьцаагаар натри, калийн агуулга $\left(\mathrm{Na}^{+}+\mathbf{K}^{+}>\right.$ $\mathbf{M g}^{2+}>\mathrm{Ca}^{2+}$ ) зонхилж байв. Тэдгээр нууруудын усанд давс, хужирын эрдэсжилт зонхилох бөгөөд зарим нуурын усанд магнийн катион $\left(\mathbf{M g}^{2+}>\mathrm{Ca}^{2+}>\mathrm{Na}^{+}+\mathrm{K}^{+}\right)$ихсэж эрдэсжилт нэмэгдэн, усны рН -7.4-9.4 хүрч байгааг шинжилгээний дүнгээр тогтоов. Энэ нь газрын гадаргуугийн өндөрлөгөөс хамааран усны ууршилт ихсэх, нарны цацрагийн тусгалын нөлөө зэрэг олон хүчин зүйлээс нуурын усны эрдэсжилтийг нэмэгдүүлж байгааг харуулж байна. Эдгээр өндөр эрдэсжилттэй нуурын усанд литий, уран болон бусад дагалдах микроэлементийн агуулга ихэсч байгааг тогтоов. Их Нууруудын хотгорт байрших нууруудад натрий, калийн карбонатын эрдэсжилттэй харилцан хамааралтай ураны хэмжээ $\mathrm{U}^{238}$ 0.1-1.0 мг/л хүртэл хэлбэлзэж $\mathrm{UO}_{2}\left(\mathrm{CO}_{3}\right)_{2}{ }^{2-}$, $\mathrm{UO}_{2}\left(\mathbf{C O}_{3}\right)_{3}{ }^{4-}, \mathbf{U O}_{2}\left(\mathbf{C O}_{3}\right)^{0}$ гэх мэт карбонат уранилийн нэгдэлүүд үүсч байна. Үүнээс гадна бор (>100 мг/л), бром (>460 мг/л), литий (>50 мг/л), стронции (>8 мг/л) -ийн агуулга өндөр болж байна. Шаазгай нуурын усанд дээрхи элементээс гадна мышъякийн агуулга их байгаа нь нуурын ус экологийн хор нөлөөтөй гэдгийг харуулж байна. Ураны өндөр агуулга нь нууруудын усны натри, хлор, бикарбонат, карбонат ион, $\mathrm{pH}$, мышъяктай эерэг хамаарал үүсгэх бөгөөд харин нуурын усны магний, кальций, калийн катион, сульфатын ионтой эсрэг хамааралтай хуримтлагдаж байгааг илрүүлэв.

Нуурын усанд агуулагдах уран, литийн агуулга тухайн газар нутгийн эргэн тойрны уулын чулуулгийн тогтоц, найрлагаас ихээхэн хамааралтай байдгийг тогтоов. Энд доорхи 2 нуурын судалгааг жишээ болгож байна. Үүнд:

Увс аймгийн Ховд, Өмнөговь сумын зааг дээр оршдог гадагшаа урсгалгүй Шаазгай нуурын хужиртай усны найрлагыг онцлон авч үзье. Энэ нуур нь далайн төвшинөөс дээш 1703 м өндөрт оршдог бөгөөд энэ нуур руу жижиг булаг шүүрч ордог. Усны захаас 10 м дотогшлоход гүн нь 75 см болно. Нуур нь шүлтлэг найрлагатай боржин чулуулгаар хүрээлэгдсэн хотгорт орших ба нуурын ойролцоо ураны илрэлтэй газар оршдог болох нь геологи-хайгуулын зураглалын ажлаар 
тогтоогдсон байдаг. Иймд уг шүлтлэг чулуулгийн элэгдэл, ураны илрэл зэрэг нь нуурын усны хагалбарыг дагаж нуурын усанд эрдэсжилтийг нэмэгдүүлдэг болж болох юм. Шаазгай нуурын усны эрдэсжилт 13,56 г/л, pH-9.4 бөгөөд эрдэсжилтийн ихэнхийг бикарбонат натрийн давс эзэлдэг. И.П.Исупов $[2010,2011]$ нарын судалгааны үр дүнд нуурын усанд ураны хэмжээ (238U -1.0 мл/л) өндөр ба нуурт цутгаж байгаа /булгын усны-хасах/ жижиг горхины усны эрдэсжилт бага (0,2 мг/л) боловч ураны агуулга ( ${ }^{238} \mathrm{U}-0.03$ мл/л) харьцангуй их байгааг тогтоосон юм. Энэ нутагт амьдардаг /Нутгийн хасах/ олон хүний элэг, уушиг өвддөг тухай ярьж байв. Нуурт цутгадаг булгийн усны найрлаганд уран, молибден, мышъяк (хүнцэл) зэрэг элементийн агуулга өндөр гарсан нь уг булгийн ус хүн малын ундны хэрэгцээг хангахгүй байгааг харуулж байна. Хэдийгээр энэ нь орон нутгийн шинжтэй ч тэр хавийн малчин ард иргэдийн эрүүл мэндэд хортой нөлөө үзүүлж байж болох талтай. Иймээс цаашид нуур, булгийн усны судалгааг үргэлжлүүлэх, тухайн нутгийн геологийн тогтоц, гидрохими, усны ховор элементийн судалгааг хийхдээ эрүүл мэндийн байгууллагатай хамтрах нь чухал болж байна.

Увс аймгийн Өлгий сумаас 20 км-ийн хойно уртрагийн дагуу ялимгүй сунаж тогтсон зууван хэлбэртэй жижиг (N:49013`44,8”.E:9203’0.7”) шорвог давстай Давсан буюу Олгой нуур оршдог . Энэ нуур нь нилээд хотгор газарт, далайн төвшинөөс дээш 1515м өндөрт нуур, голын элсэнцэр, шавранцараар хучигдсан бөгөөд нуурын зүүн талд вэнд-кембрийн хувирсан чулуу, зануужин, хөрзөн зэрэг метаморф хурдас илэрсэн байна. Нуурын зүүн талаар дөрөвдөгчийн хучаасны доороос девоны настай шүлтлэг лейкократ гранитын биетүүд хэсэг хэсэг газарт ил гарсан ба тэдгээртэй холбоотой ховор металлын илрэлүүд, мөн хувирмал чулуулгууд дотор алт, мөнгө, зэс, төмөрийн илрэлүүд зураглалын ажлаар тогтоогджээ. Уг жижиг нуур нь Цагааншивээтийн гол хагарлыг дагасан олон хагарлуудын уулзварт байрласан бөгөөд /энэ нуурын усанд хийсэн хасах/ бидний 2008, 2009 онуудын гидрохимийн судалгааны ажлын үр дүнгээр уг нуур нь шорвог давстай ба нуурын усанд литийн агуулга өндөр буюу 2,90-100 мг/л-ийн хооронд хэлбэлзэж бром (1г/л), бор (185 г/л), стронци (10 г/л) хүрч байсан нь литийн эрдэст усны шинэ төрлийн илрэл болох боломжтойг харуулсан юм. /агуулгууд г/л уу???/

Монголын баруун хойт нутаг, Говийн Алтайн нутгуудад литий, бром, борын өндөр эрдэсжилт бүхий давстай нууруудыг илрүүлж хэтийн төлөвтөй болохыг тогтоосон юм. Цаашид Увс аймгийн Давсан нуур (хэмжээ) ба нуурын ойр орчмын ус хураагуурын геоморфологи, гидрохими, мониторингийн судалгааг (нуурын орчны динамикийн өөрчлөлт, эрдэсжилтийн хэмжээ ба өндөр эрдэсжилттэй усны ашигт бүрэлдэхүүний агуулгыг тогтоох) хийх, мөн Говь Алтай аймгийн Сангийн далай нуур, Хулам нуур, Тонхил нуур, Увс аймгийн Сангийн далай нууруудын геоморфологи гидрогеохимийн мониторингийн судалгаа болон ойролцоох усан сангийн (динамик шилжилтйн талбай, нуурын эрдэсжилт, дайвар элементийн агуулга) судалгааг явуулахаар төлөвлөж байна.

Тэдгээр давстай нууруудын ус, тэдгээрийн ёроолын хурдсанд литий, бром, борын агуулга өндөр гарсан ба цаашид судалгааг үргэлжлүүлж таамаг нөөцийн үнэлгээ хийгдэх юм.

Говийн бүсийн иэрдийн хотгорт орших булаг, шандны усны найрлаганд эрдэсжилтийн хэмжээ харьцангуй бага илэрсэн бөгөөд тэдгээрт литийн агуулга 0,01 мг/л, ба Цагаан элсний нефтийн ордын гүний усны дээжинд литий ойролцоогоор 0,23 мг/л агуулгатай байв. Ихэнхи нуурын усанд ${ }^{238} \mathrm{U}-0,087$ мг/л, B-90 мг/л, Br-60 
мг/л агуулгатай байна. Харин зарим нуурын ёроолын хурдасны наанги эрдсүүдэд литийн агуулга ихэсч (300 мг/л) байсан болно. Иймд мезозойн хотгоруудын хурдас хуримтлал дахь наангилаг хурдсанд литийн агуулга их байх магадлалтай юм.

\section{Дүгнэлт}

Монгол орны Их Нууруудын Хотгор, Нууруудын хөндий, Дорнод Монгол, Говийн бүсийн хэмжээнд тархсан 50 гаруй эрдэст нуурын хурдас, усны дээжинд литий, уран болон бусад ховор элементийн гидрогеохимийн шинжилгээг хийж уран, литийн инфильтрацийн гаралтай эрдэст усан орд үүсгэх боломжтой гэсэн урьдчилсан дүгнэлтэнд хүрээд байна. Уг судалгаагаар манай орны ураны хүдэржилттэй талбайд байршилттай гадагш урсгалгүй нууруудын гидрокарбонатын эрдэсжилттэй нуурууд (Шаазгай, Хяргас нуур г.м) нь ураны түгэээмэл биш төрлийн хүдэржилтийг үүсгэж болох юм гэж үзэв. Түүнчлэн шорвог давстай нууруудын (Хулам нуур, Бага гашуун нуур Шорвог нуур г.м) усанд литийн агуулга өндөр байгааг тогтоолоо. Баруун Монголын нилээд хэдэн гадагш гарцгүй эрдэсжилт ихтэй нууруудад литий, уран зэрэг ховор металл болон ховор элементийн (B, Br, Sr) агуулга өндөр хэмжээтэй байгаа нь /нэг төрлийн-хасах/ литий, ураны өндөр агуулгатай нуурын төрлийн орд, илрэлийг илрүүлэх эрэл-хайгуулын нэг шинж боловч цаашид судалгааг үргэлжлүүлэн тектоник-магматизм, галт уулын чулуулгийн бялхалт, нүүрсхүчлийн ба азотын халуун рашаан, геоэкологийн судалгаатай хамтатган цогц судлах шаардлагатай г харуулж байна.

Зарим эрдэст нуурын (Бэгэр, Бор овоо г.м) усны найрлаганд хоолны давс, хужир, магний, карбонат давамгайлж байгаа хэдий ч S-As, Sr зэрэг экологийн хор нөлөөтөй элементүүд ихсэн, литий, уран бусад дагалдах микроэлементийн хэмжээ нилээд өндөр байгааг харгалзан дээрх эрдэст нуурын давсыг хүнсэнд ашиглахдаа анхаарах, тэдгээрт геоэкологийн үнэлгээ хийх, нуурын микроэлементийн агуулгыг тодорхойлох зэрэг цогцолбор ажлуудыг явуулах нь зохистой болж байна. Мөн Баруун Монголын ураны потенциал хүдэржилттэй нуурын ойролцоох усан сангаас эх авсан булаг, горхины усыг ундны хэрэгцээнд хэрэглэхгүй байх талаар эрүүл мэндийн байгууллагатай хамтарсан төсөл хэрэгжүүлэх нь зүйтэй гэж үзэв.

Уг судалгааны ажлыг 2009-2010 онд хэрэгжүүлсэн Монгол-Оросын ШУАийн хамтарсан РФФИ-Монг_а № RUS-09/018 “Төв Азийн эрдэсжилт ихтэй нууруудын хүдэр бүрдүүлэх нөхцөл ба литий, уран агуулсан усан- эрдэст ордуудыг илрүүлэх шинэ аргуудын физик, химийн үндэс" нэртэй суурь шинжлэх ухааны төслийн шугамаар гүйцэтгэв.

\section{Ишлэл}

1. Ариунбилэг С., Исупов В.П., Владимиров А.Г., Кривоногов С.К., Шацкая С.С., Куйбида Л.В. Микрокомпонентный состав минерализованных вод Восточной Монголии //Mongolian geoscientist. 2009. v.35. pp 115-116.

2. Ариунбилэг С., Исупов В.П., Владимиров А.Г., Кривоногов С.К., Шацкая С.С., Куйбида Л.В. Эрдэсжилттэй нууруудын микроэлементийн судалгаа //Монгол орны геодинамик ба металлогенийн асуудлууд,ШУА-ийн ГЭБХ-ийн бүтээл №19 .2009, х.177-180.

3. Исупов В. П., Владимиров А. Г., Шварцев С. Л., Ляхов Н. З., Шацкая С. С., Чупахина Л. Э., Куйбида Л. В., Колпакова М. Н., Ариунбилэг Содов, Кривоногов С. К. Химический состав и гидроминеральные ресурсы соленых озер Северо-Западной Монголии. // 
Химия в интересах устойчивого развития. 2010 .( в печати).

4. Исупов В.П., Владимиров А.Г., Ляхов Н.З., Шварцев С.Л. Ариунбилэг С, Колпакова М.Н., Шацкая С.С., Чупахина Л.Э., Куйбида Л.В., Мороз Е.Н. Ураноносность высокоминерализованных озер Северо-Западной Монголии. //ДАН,2011, том 437, №1,c.1-5.

5. В.ПИсупов,А.Г.Владимиров, С.Л.Шварцев, С.Ариунбилэг,М.Н.Колпакова, С.С.Шацкая, Л.Э.Чупахина, Л.В. Куйбида, Е.Н. Мороз. Урановые ресурсы минерализованных озер Северо-Западной Монголии // Труды ИГ МР АН М.2010, Вып.20, стр.

6. Лувсандорж Ш. Минеральные озера Монголии и возможности использования их солей. - Улан-Батор, Изд-во АН МНР, 1973. - 147 с. (На монг).

7. Рассказов А.А., Лувсандорж Ш. Севастьянов Д.В.и др, Озера МНР и их минеральные ресурсы. - М.: Наука, - 1991, 136 с.

8. Писарский Б.И., Ганчимэг Д. Газовый состав подземных минеральных вод Монголии, Иркутск, 2007, 106 с.

9. Цалолихин С.Я 1985, Немады пресных и солоноватых вод Монголии, ССМКБЭ, том 25, Л.: Наука, 115 с.

10. Цэрэнсодном Ж. Монгол орны нуурын каталог. Улаанбаатар: Шувуун Саарал. 2000. $141 \mathrm{x}$.

11. Garrett D. Handbook of Lithium and Natural Calcium Chloride. Their Deposits, Processing, Uses and Properties. Elsevier. 2004. 457 p.

12. Goro Komatsu et al., Paleo shoreline geomorphology of Boon Tsagaan Nuur, Tsagaan Nuur and Orog Nuur: the Valley of Lakes, Mongolia. Elsevier, Geomorphology 39, 2001., pp. 83-98

13. Linhoff, B. S.; Bennett, P.; Puntsag, T. Uranium Geochemistry in Hyper saline Soda Lakes in Eastern Mongolia: Uranium Geochemistry in American Geophysical Union, Fall Meeting, abstract \#H11C-0685, 2007.

14. Mingkuan Qin. Technical Meeting on Uranium from Unconventional Resources. $4-6$ November 2009, IAEA, Head quarters, Vienna. 